\title{
Validation of organ culture in colonic adaptation to surgical manipulation
}

\author{
G V N Appleton, E E Wheeler, D N Challacombe, R C N Williamson
}

\begin{abstract}
Valuable information on intestinal adaption can be gained by using the technique of organ culture to measure the crypt cell production rate. It is not known, however, whether the production rate in organ culture accurately represent that in vivo. Colonic crypt cell production rate, determined by a standard method in vivo, was compared with that in vitro in organ culture in 56 rats. Extensive jejunoileal bypass was used to stimulate colonic hyperplasia, and colonic defunction (by transverse colostomy) led to hypoplasia. There were no differences in crypt cell production rates between in vivo and in vitro groups in normal colon $(4.62(0.39) v$ $4.80(0.23)$ cells/crypt/hour), after $80 \%$ jejunoileal bypass $(7.81(0.71) v 6.75(0.72)$ cells/ crypt/hour), or after defunction $(2 \cdot 11(0 \cdot 39) v$ $1.81(0.35)$ cells/crypt/hour). Adapting colonic mucosa does not undergo appreciable readaptation in vitro in short term organ culture (10-24 hours). Crypt cell production rate results obtained in man probably reflect in vivo values.
\end{abstract}

The close relation between colorectal adaptation and experimental carcinogenesis ${ }^{1}$ suggests that the rate of cell turnover in human intestine may reflect an individual's susceptibility to colorectal cancer. Recent cytokinetic studies in man have shown that the large bowel adapts in a similar fashion to that of the rat when subjected to defunction (hypoplasia) ${ }^{2}$ or small bowel bypass (hyperplasia). ${ }^{3}$

The most robust index of cytokinetic change in the gastrointestinal tract is the crypt cell production rate. ${ }^{4}$ Although attempts have been made to measure this in man in vivo, ${ }^{5}$ ethical constraints now limit such measurements to in vitro methods. The technique of organ culture aims to preserve the structural and functional equilibrium of a biopsy specimen so that the crypt cell production rate can be determined by stathmokinetic methods. By paying careful attention to detail, it is possible to preserve intestinal mucosa in organ culture so that after 18-36 hours tissue is histologically ${ }^{6}$ and ultrastructurally ${ }^{7}$ indistinguishable from normal. A major uncertainty of organ culture is whether cytokinetics are substantially changed in mucosa removed from its usual milieu. If mucosa is hyperplastic (or hypoplastic) in vivo, will the observed crypt cell production rate in vitro also be higher (or lower) than normal after 15-21 hours culture in the absence of systemic and local environmental influences?

This study was designed to compare the crypt cell production rate in vivo, using a standard technique in the rat, with that in vitro, using a rat model of organ culture. Surgical stimuli to hyperplasia and hypoplasia were provided by $80 \%$ jejunoileal bypass and proximal defunctioning colostomy respectively.

\section{Methods}

ANIMALS AND OPERATIONS

Fifty six male Sprague-Dawley rats weighing mean (SD) 220 (29) g were used. Half the animals were allocated to an in vivo stathmokinetic experiment in which 10 rats underwent $80 \%$ jejunoileal bypass with end to side anastomosis between the proximal jejunum and distal ileum, eight rats had an end colostomy raised in the transverse colon (thereby defunctioning the distal colorectum), and 10 unoperated rats acted as controls.

For the organ culture experiment, fewer animals were used because of the large number of explants available from each rat. Five rats had an $80 \%$ jejunoileal bypass, eight had a transverse colostomy, and five acted as controls. More rats were used in the colostomy group to harvest adequate samples for organ culture because the defunctioned colon was shorter in length and calibre. The remaining animals $(n=14)$ had no operation and were used (a) in a dose-response experiment for vincristine in organ culture $(n=3)$, or $(b)$ to determine the optimum duration of organ culture $(n=11)$. Two rats died of anastomotic leakage after jejunoileal bypass, leaving eight healthy survivors in the in vivo group and three in the vitro group. Rats were killed four weeks after operation.

\section{STATHMOKINETIC METHOD IN VIVO}

Crypt cell production rate measurement in vivo was carried out along the lines of a well established technique. ${ }^{8}$ On the day of killing (four weeks after operation) rats were weighed and then injected intraperitoneally with $1 \mathrm{mg} / \mathrm{kg}$ vincristine (Oncovin, Eli Lilly, Basingstoke). Injections were always carried out between 9.00 and 9.30 am to minimise diurnal fluctuations in the crypt cell production rate. ${ }^{9}$ Animals were killed at 30 minute intervals $30-180$ minutes after vincristine injection. Segments of descending colon were excised, washed in saline, and fixed in Carnoy's fluid. After two to six hours, specimens were transferred to $70 \%$ ethyl alcohol for storage until needed. Later, bowel segments were removed and flattened, and a small piece $\left(3 \mathrm{~mm}^{2}\right)$ was excised. Specimens were stained with Schiff's reagent by Feulgen's reaction. The muscle layer was stripped away leaving the mucosa to be teased apart under a dissecting microscope until crypts were sufficiently separated. Microscopic examination then 
TABLE I Vincristine dosage and metaphase arrests (mean $(S E M))$

\begin{tabular}{ll}
\hline Dose of vincristine $(\mu \mathrm{g} / \mathrm{ml})$ & $\begin{array}{l}\text { Mean no of metaphase arrests } \\
\text { after } 3 \text { hr organ culture }\end{array}$ \\
\hline 0.05 & $7 \cdot 38(1 \cdot 06)^{\star}$ \\
$0 \cdot 10$ & $10 \cdot 32(1 \cdot 87)^{\star}$ \\
0.20 & $11.94(3.43)^{\star}$ \\
0.40 & $16.44(4 \cdot 06) \dagger$ \\
0.60 & $17 \cdot 17(2 \cdot 02)$ \\
0.80 & $17.50(1.50)$ \\
\hline
\end{tabular}

*Many anaphases seen; toccasional anaphases seen

enabled magenta stained metaphases to be counted in 20 crypts per specimen. In both parts of the experiment the observer counted the number of metaphases blind, being unaware of the origin of each specimen.

The mean number of arrested metaphases/ crypt was plotted against time of death after vincristine. The slope of the line fitted to these data by linear regression analysis and least squares approximation represents the crypt cell production rate in cells/crypt/hour. ${ }^{8}$

\section{STATHMOKINETIC METHOD IN VITRO}

After four weeks, dose-response and duration experiments were performed on mucosal samples obtained from the lower descending colon by the 'rocking' method of organ culture we have previously described. ${ }^{3}$ Bowel segments were opened longitudinally and washed in ice cold medium (see below). The muscle coat was stripped away from the mucosa using two pairs of watchmakers' forceps. Under aseptic conditions, mucosal segments were flattened and gently orientated on a metricel filter with the luminal surface uppermost. The mucosa was divided into $2-3 \mathrm{~mm}^{2}$ explants that were placed on stainless steel grid platforms sited at one end of the well of a Lux multiwell culture dish (Flow Labs).

Culture medium was CMRL-1066 (Gibco) $91 \cdot 5 \% \mathrm{v} / \mathrm{v}$, heat inactivated fetal calf serum $5 \%$, L-glutamine $200 \mathrm{mmol} / \mathrm{l} 2 \%$, Hepes buffer $1 \mathrm{~mol} / 1 \mathrm{1} \%$, and penicillin + streptomycin 10000 $\mathrm{IU} / \mathrm{ml} 0.5 \%$. Glucose $20 \mathrm{mg}$, hydrocortisone 21 -hemisuccinate $1 \mathrm{mg}$, and insulin $1 \mathrm{mg}$ were added to each $20 \mathrm{ml}$ of medium, which had a final $\mathrm{pH}$ of $7 \cdot 2-7 \cdot 3$. Each well contained $3 \mathrm{ml}$ of the final medium. Wells were placed in a controlled atmosphere chamber (Bellco, New Jersey, USA) and were rocked at 3 cycles/minute on a rocking platform (Bellco) in $95 \%$ oxygen and $5 \%$ carbon dioxide at $37^{\circ} \mathrm{C}$ in a moist atmosphere.

To determine the minimum dose of vincristine required for complete metaphase arrest in cultured rat descending colon, varying doses between $0.05-0.8 \mu \mathrm{g} / \mathrm{ml}$ were added to the culture medium after 18 hours. Explants were removed three hours later, and the number of arrested metaphases was counted (as above) in 20 microdissected crypts per specimen. The maximum mean number of metaphase arrests was seen when $0 \cdot 4-0.8 \mu \mathrm{g} / \mathrm{ml}$ of vincristine had been used (Table I). In view of occasional anaphase figures seen when using $0.4 \mu \mathrm{g} / \mathrm{ml}$, a dose of $0.5 \mu \mathrm{g} / \mathrm{ml}$ was chosen for future studies. No metaphase escape has been noted using this dosage.
To discover the optimum duration of culture before metaphase arrest, vincristine $0.5 \mu \mathrm{g} / \mathrm{ml}$ was added to different culture wells at three hourly intervals from the initiation of culture to 21 hours. Specimens were removed one, two, and three hours later and fixed in Carnoy's fluid. The crypt cell production ratio was then determined separately for each three hour period of culture by the method outlined for the in vivo group. In view of the considerable numbers of samples cultured, this latter experiment was carried out on three separate occasions. Quite a high crypt cell production ratio $(4 \cdot 10(0 \cdot 41)$ cells/ crypt/hour) was found during the period six to nine hours. Over the first three to six hours of organ culture, the mucosa was in a 'shock' phase with few metaphase figures seen (Table II). By 24 hours the ratio had fallen to $1 \cdot 18(0.54)$ cells/ crypt/hour. Satisfactory values for crypt cell production ratio were obtained after either an 18 or a 21 hour period of culture (Table II); the shorter period (18 hours) was chosen for rat organ culture.

Numbers of arrested metaphases were determined separately at the centres and close to the edges of 25 control samples after 18 hours' culture and a further three hours' stathmokinesis. There was no significant difference between the two groups: values were $16.09(1 \cdot 87)$ cells/crypt/ hour at the 'centre' and 15.58 (1.81) at the 'edge'.

Four weeks after operation, mucosal specimens (from the descending colon) from rats with jejunoileal bypass, defunction, and controls were established in organ culture. After 18 hours, vincristine $0.5 \mu \mathrm{g} / \mathrm{ml}$ was added. Specimens were removed one, two, and three hours later. The crypt cell production ratio was calculated for each group (as above).

\section{STATISTICAL ANALYSIS}

Crypt cell production rates were compared using Student's $t$ test. Mean number of metaphase arrests were compared using the Mann-Whitney $\mathrm{U}$ test.

\section{Results}

CRYPT CELL PRODUCTION RATE IN VIVO (TABLE III) The crypt cell production rate in normal lower descending colon was $4.62(0.47)$ cells/crypt/ hour. This value was similar to that seen in previous experiments in our laboratory. After $80 \%$ jejunoileal bypass the production rate rose by $69 \%$. After proximal colostomy it fell by $55 \%$.

CRYPT CELL PRODUCTION RATE IN VITRO (TABLE III) Explants were well preserved after 18 hours'

TABLE III Crypt cell production rate $(C C P R)$ in vivo and in vitro (Mean (SEM))

\begin{tabular}{lll}
\hline Group & $\begin{array}{l}\text { CCPR in vivo } \\
(\text { cells/crypt/hr })\end{array}$ & $\begin{array}{l}\text { CCPR after } 18 \mathrm{hr} \text { organ } \\
\text { culture }(\text { cells/crypt/hr })\end{array}$ \\
\hline Control & $4 \cdot 62(0 \cdot 39)$ & $4 \cdot 80(0 \cdot 23)$ \\
$80 \%$ JIB & $7 \cdot 81(0 \cdot 71)^{\star}$ & $6 \cdot 75(0 \cdot 72) \dagger$ \\
Defunctioned & $2 \cdot 11(0 \cdot 39)^{\star}$ & $1 \cdot 81(0 \cdot 35) \dagger$ \\
\hline
\end{tabular}

${ }^{\star} \mathrm{p}<0.01 v$ in vivo controls; $\mathrm{tp}<0.02 v$ organ culture controls. $\mathrm{JIB}=$ jejunoileal bypass. 


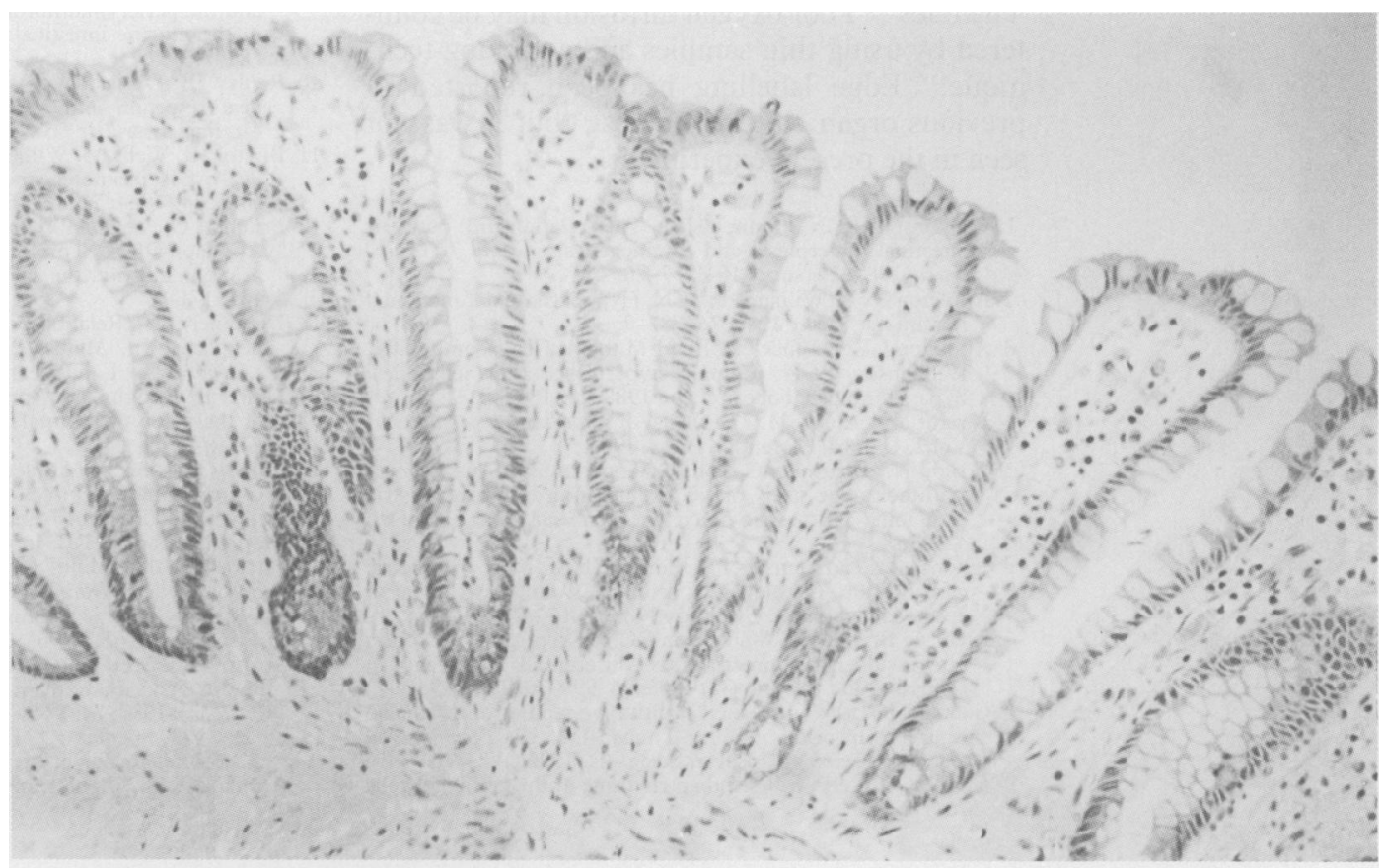

Histological section of colonic mucosa after 18 hours organ culture (Haematoxylin and eosin, original magnification $\times 200$.)

culture (Figure) and a further three hours' stathmokinetic period. The crypt cell production rate for normal rat descending colon in organ culture was $4.80(0 \cdot 23)$ cells/crypt/hour. The accumulation of metaphase arrests after vincristine administration adhered closely to a linear pattern. After $80 \%$ jejunoileal bypass the crypt cell production rate rose by $41 \%$. In defunctioned colon the crypt cell production rate fell by $62 \%$. There were no significant differences between in vivo and in vitro results in any of the three study groups.

\section{Discussion}

This study indicates that crypt cell production rate measurements in organ cultured rodent colonic mucosa are very similar to values obtained by a standard stathmokinetic technique in vivo. It is reassuring for studies of human colonic cytokinetics to learn that abnormal rates of experimental cell proliferation in vivo continue to be expressed in short term organ culture. An 18 hour culture period has been found to be satisfactory for evaluation of the crypt cell production rate in the rat. It seems that during this time normal or adapting mucosa does not undergo appreciable readaptation to the new surroundings.

After $80 \%$ jejunoileal bypass the increase in the colonic crypt cell production rate in vivo $(69 \%)$ was relatively modest compared with the $100 \%$ rise previously found after $33 \%$ distal jejunoileal bypass ${ }^{10}$ or the $234 \%$ increase after subtotal $(85 \%)$ bypass. ${ }^{11}$ The experimental conditions were different, however, since azoxymethane used in the first study is known to stimulate cell proliferation, and the effect of subtotal bypass was measured at 30 weeks. In cultured mucosa, the crypt cell production rate after jejunoileal bypass was (a non-significant) 14\% less than in vivo, suggesting the possibility that removal from local luminal, systemic, or hormonal in- fluences might lead to a brisk reversion of the hyperplastic state. It is desirable that the minimum culture period should be used after allowing tissue to settle down in vitro.

There is a severe 'shock' phase during the first few hours of rat colonic organ culture when few cells undergo mitosis. This finding confirms previous work showing depression of mitosis in early organ culture. ${ }^{12}$ Many studies in man and animals have shown that labelling of DNA takes place when colonic mucosa in vitro is exposed to tritiated thymidine for one hour. ${ }^{13}$ It seems that cells continue to synthesise DNA but do not enter mitosis, presumably because of a G2 block. In the present experiment a limited surge in the number of labelled mitoses was found during the six to nine hour period of culture. It is possible to speculate that both G1 and G2 blocks occur during the first six hours of organ culture and are then released. Cells in G2 at the start of culture would enter mitosis six hours later producing an early 'peak', whereas cells in G1 would begin to enter $S$ phase at six hours and then move on to metaphase after a further six to 12 hours, so producing the second peak at 18 hours. This hypothesis is in accordance with previous estimates of six to nine hours for the duration of the $S$ phase in rat descending colon. ${ }^{14}$ Circadian variation in proliferative indices also affects the G1 and G2 phases of the cell cycle specifically. ${ }^{4}$

In a recent study comparing in vivo and in vitro measurements of crypt cell production rate in normal colonic mucosa from Wistar rats, Finney and colleagues found that the birth rate at the edge of explants was more than twice that in the centre. ${ }^{15}$ The higher crypt cell production rate correlated closely with in vivo estimation. Possible explanations for this phenomenon are either a relative lack of oxygen diffusion causing central necrosis and inhibition in cell turnover in the explant, ${ }^{16}$ or an outgrowth of stimulated epithelial cells at the cut edge of samples owing to loss of local controlling tissue factors such as 
'chalones'. ${ }^{17}$ Poor oxygen diffusion may be countered by using thin samples and a rocking technique. ${ }^{18}$ Edge labelling has been reported in previous organ culture studies, ${ }^{19}$ but it was not seen in the present experiment.

1 Williamson RCN, Rainey JB. The relationship between intestinal hyperplasia and carcinogenesis. Scand $\mathcal{f}$ Gastroenterol 1984; 19 (suppl 104): 57-76.

2 Appleton GVN, Williamson RCN. Hypoplasia of defunctioned rectum. Brf Surg 1989; 76: 787-9.

3 Appleton GVN, Wheeler EE, Al-Mufti R, Challacombe DN Williamson RCN. Colonic hyperplasia after jejunoileal Williamson RCN. Colonic hyperplasia after
bypass for morbid obesity. Gut 1988;29: 1544-8.

4 Wright NA, Alison M. The biology of epithelial cell populations. Vol 2. Oxford: Clarendon Press, 1984.

5 Wright NA, Britton DC, Bone G, Appleton DR. An "in vivo" stathmokinetic study of cell proliferation in human gastric carcinoma and gastric mucosa. Cell Tissue Kinet 1977; 10 429-36.

6 Jakobsen A, Kristensen PB, Poulsen HK. Flow cytometric classification of biopsy specimens from cervical intraepithelial neoplasia. Cytometry 1983; 4: 166-70.

7 Allan A, Bristol JB, Williamson RCN. Crypt cell production rate in ulcerative proctocolitis: differential increments in remission and relapse. Gut 1985; 26: 999-1003.

8 Goodlad RA, Wright NA. Quantitative studies on epithelial replacement in the gut. In: Titchen DA, ed. Techniques in replacement in the gut. In: Titchen DA, ed. Technic
digestive physiology. Elsevier Scientific, 1982: 1-23.

9 Neal JV, Potten CS. Circadian rhythms in the epithelial cells and the pericryptal fibroblast sheath in three different sites in the murine intestinal tract. Cell Tissue Kinet 1981; 14 in the

10 Rainey JB, Davies PW, Williamson RCN. Relative effects of ileal resection and bypass on intestinal adaptation and

11 Bristol JB, Wells M, Williamson RCN. Adaptation to jejunoileal bypass promotes experimental colorectal carcinogenesis. BrF Surg 1984; 71: 123-6.

12 Pritchett CJ, Senior PV, Sunter JP, Watson AJ, Wilson RG Appleton DR. Cell proliferation in human colorectal mucos in organ culture: the early adaptive changes. $\mathcal{F}$ Anat 1985 141: 171-9.

13 Deschner EE. Relationship of altered cell proliferation to neoplasia. In: Malt RA, Williamson RCN, eds. Colonic carcinogenesis. Lancaster: MTP Press 1982: 25-30.

14 Sunter JP, Wright NA, Appleton DR Cell population kinetics of the colon of the male rat. Virchows Arch $[B] 1978 ; 26$ : of the color $275-87$.

15 Finney KJ, Ince P, Appleton DR, Sunter JP, Watson A. A comparison of crypt-cell proliferation in rat colonic mucosa in vivo and in vitro. $\mathcal{F}$ Anat $1986 ; 149$ : $177-88$

16 Meyer JS, Connor RE. In vitro labelling of solid tissues with tritiated thymidine for autoradiographic detection of S-phase nuclei. Stain Technol 1977; 52: 185-95.

17 Bulloch WS. Mitotic and functional homeostasis: a speculative review. Cancer Res 1965; 25: 1683-1827.

18 Autrup H, Barrett LA, Jackson FE, Jesudason ML, Stoner G, Phelps P, et al. Explant culture of human colon. Gastroenterology 1987; 74: 1248-57.

19 Shorter RG, Spencer RJ, Hallenbeck GA. Kinetic studies of the epithelial cells of the rectal mucosa in normal subjects the epithelial cells of the rectal mucosa in normal subiect

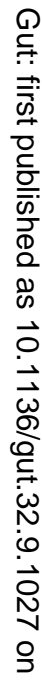

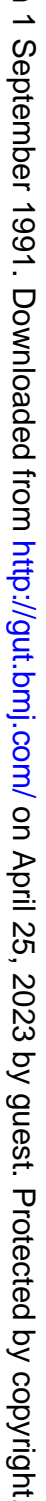

